\title{
Phase I and pharmacokinetic study of capecitabine and the oral mTOR inhibitor everolimus in patients with advanced solid malignancies
}

\author{
Maarten J. Deenen • Heinz-Josef Klümpen • Dick J. Richel • Rolf W. Sparidans • \\ Mariette J. Weterman • Jos H. Beijnen • Jan H. M. Schellens • Johanna W. Wilmink
}

Received: 8 June 2011 / Accepted: 18 July 2011 / Published online: 2 August 2011

(C) The Author(s) 2011. This article is published with open access at Springerlink.com

\begin{abstract}
Summary Background Everolimus is an oral mTORinhibitor. Preclinical data show synergistic effects of mTOR inhibition in combination with 5-fluorouracil-based anticancer therapy. The combination of everolimus with capecitabine seems therefore an attractive new, orally available, treatment regimen. Patients and methods Safety, preliminary efficacy and pharmacokinetics of everolimus in combination with capecitabine were investigated in patients with advanced solid malignancies. Patients were treated with fixed dose everolimus $10 \mathrm{mg} /$ day continuously, plus capecitabine bid for 14 days in three-weekly cycles. Dose escalation of capecitabine proceeded according to the
\end{abstract}

M. J. Deenen · J. H. M. Schellens

Division of Clinical Pharmacology, Department of Medical

Oncology, The Netherlands Cancer Institute,

Amsterdam, The Netherlands

M. J. Deenen · J. H. M. Schellens

Department of Experimental Therapy,

The Netherlands Cancer Institute,

Amsterdam, The Netherlands

H.-J. Klümpen · D. J. Richel • M. J. Weterman •

J. W. Wilmink $(\square)$

Department of Medical Oncology,

Academic Medical Center Amsterdam,

Meibergdreef 9,

1105 AZ Amsterdam, The Netherlands

e-mail: j.w.wilmink@amc.uva.nl

R. W. Sparidans $\cdot$ J. H. Beijnen · J. H. M. Schellens

Faculty of Science, Department of Pharmaceutical Sciences,

Division of Biomedical Analysis, University Utrecht,

Utrecht, The Netherlands

J. H. Beijnen

Department of Pharmacy \& Pharmacology,

Slotervaart Hospital Amsterdam,

Amsterdam, The Netherlands standard $3 \times 3$ phase I design in four predefined dose levels $\left(500-1,000 \mathrm{mg} / \mathrm{m}^{2}\right.$ bid). Results In total, 18 patients were enrolled. Median (range) treatment duration with everolimus was 70 days (21-414). Capecitabine $1,000 \mathrm{mg} / \mathrm{m}^{2}$ bid combined with $10 \mathrm{mg} /$ day everolimus was declared the maximum tolerated dose, at which level one patient developed dose-limiting toxicity (stomatitis grade 3). Drug-related adverse events were mostly grade $\leq 2$ and included mainly fatigue (56\%), stomatitis (50\%), and handfoot syndrome (33\%). Partial response was documented in three patients, and four had stable disease. There was no pharmacokinetic interaction between everolimus and capecitabine. Conclusion Everolimus $10 \mathrm{mg} /$ day continuously combined with capecitabine $1,000 \mathrm{mg} / \mathrm{m}^{2}$ bid for 14 days every 3 weeks is a patient-convenient, safe and tolerable oral treatment regimen. This is the first study to demonstrate feasibility of this combination at doses with proven single agent efficacy in a number of tumors. Prolonged clinical benefit was observed in an encouraging 39\% of patients with advanced solid malignancies.

Keywords Capecitabine - Clinical pharmacology . Everolimus $\cdot$ mTOR $\cdot$ Pharmacokinetics $\cdot$ Phase I

\section{Introduction}

The PI3K/Akt pathway is an important intracellular signalling pathway that is often dysregulated in multiple types of cancers. Signal transduction of activated PI3K/Akt is transmitted through several downstream pathways, including the mammalian target of rapamycin (mTOR) $[1,2]$. Everolimus, an oral mTOR inhibitor, has demonstrated antitumor properties including inhibition of cell proliferation, cell survival and angiogenesis in preclinical 
studies [3-11]. Interestingly, in cancer cell lines synergistic anticancer effects of mTOR inhibition were observed when used in combination with 5-fluorouracil (5-FU) [12-15]. Recently, everolimus has been investigated as single agent in phase I-III clinical trials in patients with advanced renal cell carcinoma [16, 17], metastatic pancreatic cancer [18], advanced pancreatic neuroendocrine tumors [19], metastatic breast cancer [20], advanced non-small cell lung cancer [21], and in patients with various advanced solid tumors [22-24]. These trials showed that treatment with everolimus continuously at $10 \mathrm{mg}$ per day was well tolerated and showed biological activity with an acceptable side effect profile, consisting of mainly stomatitis and fatigue. Overall, the preclinical and clinical data suggest that everolimus may be more efficacious when used in combination with other anticancer drugs. Indeed, everolimus has been combined in phase I-II trials with paclitaxel [25, 26], gemcitabine [27], gefitinib [28], bevacizumab [29] and letrozole [30], and several other early clinical trials using combinations of everolimus with cytotoxic agents are currently ongoing.

Capecitabine is an oral pre-prodrug of 5-FU. Recently, capecitabine combined with everolimus has been tested in 15 heavily pretreated Korean patients with advanced gastric cancer [31]. The combination of capecitabine plus everolimus seems especially attractive due to its oral availability and easy use in an outpatient setting. This patient-friendly approach, the preclinical synergistic effects of 5-FU-based anticancer therapy and mTOR inhibition, plus the available clinical experience of mTOR inhibitors in patients with cancer served as the rationale to initiate this phase I trial of everolimus in combination with capecitabine. The purpose of this study was to determine the safety, tolerability and the pharmacokinetic interaction of capecitabine and everolimus in patients with advanced solid malignancies.

\section{Materials and methods}

Patient population

Eligible patients were aged $\geq 18$ years with histological or cytological confirmed solid malignancies refractory to standard therapies, or for whom no standard treatment existed. Other eligibility criteria included WHO performance status $\leq 2$, estimated life expectancy of $\geq 3$ months, adequate bone marrow (white blood cell count $\geq 3.0 \times 10^{9} / \mathrm{L}$, platelets $\geq 100 \times 10^{9} / \mathrm{L}$ ) and adequate hepatic and renal function (serum bilirubin $\leq 1.5 \times$ upper limit of normal $(\mathrm{ULN}), \mathrm{ALAT} / \mathrm{ASAT} \leq 2.5 \times \mathrm{ULN}$ or in case of liver metastases $\leq 5 \times$ ULN and serum creatinine $\leq 150 \mu \mathrm{mol} / \mathrm{L}$ ). Patients were ineligible if they were known with alcoholism, drug addiction and/or psychotic disorders that were not suitable for adequate follow-up. Women who were pregnant or lactating, or able to conceive but unwilling to practice effective anticonception were also excluded. All patients gave written informed consent. The study was approved by the Medical Ethics Committee of the participating institutions and was conducted in accordance with the Declaration of Helsinki and Good Clinical Practice guidelines.

Study design and treatment

This was a phase I, open-label, multi-center, dose escalation study to assess the safety, dose-limiting toxicity (DLT), maximum-tolerated dose (MTD) and the pharmacokinetic interaction of the combination of everolimus and capecitabine. The study was conducted at the Amsterdam Medical Center and the Netherlands Cancer Institute (the Netherlands). Everolimus was administered continuously twice daily (bid)

Table 1 Patient characteristics

\begin{tabular}{|c|c|c|}
\hline Characteristic & $N$ & $\%$ \\
\hline No. of patients & 18 & \\
\hline \multicolumn{3}{|l|}{ Gender } \\
\hline Male & 14 & 78 \\
\hline Female & 4 & 22 \\
\hline \multicolumn{3}{|l|}{ Race } \\
\hline White patients & 18 & 100 \\
\hline Median age, years & 61 & \\
\hline Range & $21-71$ & \\
\hline Median body surface area, $\mathrm{m}^{2}$ & 1.9 & \\
\hline Range & $1.6-2.2$ & \\
\hline \multicolumn{3}{|l|}{ WHO performance status } \\
\hline 0 & 7 & 39 \\
\hline 1 & 10 & 56 \\
\hline 2 & 1 & 6 \\
\hline \multicolumn{3}{|l|}{ Primary tumor } \\
\hline Pancreas & 7 & 39 \\
\hline Major duodenal papilla & 2 & 11 \\
\hline Esophagus & 2 & 11 \\
\hline Gallbladder & 2 & 11 \\
\hline Brain & 1 & 6 \\
\hline Osteosarcoma & 1 & 6 \\
\hline Hepatocellular carcinoma & 1 & 6 \\
\hline Unknown & 2 & 11 \\
\hline \multicolumn{3}{|l|}{ Prior anticancer therapy } \\
\hline Surgery & 10 & 56 \\
\hline Radiotherapy & 4 & 22 \\
\hline Chemotherapy & 10 & 56 \\
\hline \multicolumn{3}{|l|}{ Prior chemotherapy regimens, $\mathrm{n}$} \\
\hline 1 & 5 & 28 \\
\hline 2 & 4 & 22 \\
\hline 3 & 1 & 6 \\
\hline
\end{tabular}


at a fixed total oral dose of $10 \mathrm{mg}(5 \mathrm{mg}$ bid). The first 7 days of treatment patients were treated with single agent everolimus to reach steady state concentrations. Treatment with capecitabine started on day 8 and was given twice daily for 14 days every 3 weeks. Capecitabine was dose-escalated according to four predefined dose levels: $500,650,800$ and $1,000 \mathrm{mg} / \mathrm{m}^{2}$ capecitabine bid. At least three patients per dose level were recruited and expanded to six if one of three patients experienced DLT. Dose escalation to the next dose level was permitted if no DLT occurred in any of three or in $\leq 1$ of six patients. In case of DLT in one or more out of three, or in two or more out of six patients, that dose level was declared intolerable and no further dose escalation occurred. The immediately preceding dose level was declared the MTD. No intra-patient dose escalations were allowed. DLT was defined as any of the following events related to study treatment and occurring during the first treatment cycle: neutropenia CTC grade 4 lasting more than 5 days, CTC grade $\geq 4$ platelets or grade 3 platelets with bleeding, vomiting CTC grade $\geq 2$ or any other toxicity CTC grade $\geq 3$ (excluding alopecia), despite best supportive care. Toxicity was graded using the National Cancer Institute Common Terminology Criteria for Adverse Events (CTCAE) version 3.0 and was assessed every treatment cycle. In case of measurable disease, tumor measurements were performed at baseline and every three cycles and were evaluated in accordance with the Response Evaluation Criteria in Solid Tumors (RECIST 1.0) [32].

Pharmacokinetic analysis

To determine the pharmacokinetic interaction between everolimus and capecitabine plus metabolites, patients received (only for pharmacokinetic purposes) one single morning administration of capecitabine 7 days prior to start of treatment (day -7), at the dose level that the patient would receive at start of treatment. Plasma samples for capecitabine were obtained on day -7 (without everolimus) and on day 8 (with everolimus at steady state), both at predose and at $0.5,1,1.5,2,3,4,6$ and $8 \mathrm{~h}$ after capecitabine intake. Vice versa, blood samples for everolimus were drawn on day 7 (without capecitabine) and on day 8 (with capecitabine), both at predose and at $0.5,1,1.5$, 2, 3, 4, 6, 9 and $12 \mathrm{~h}$ after administration of everolimus. In addition, trough concentrations (immediately before the morning dose) of everolimus were determined on days 1,4 , $7,8,15,22$ and 29 to assess the formation and continuation of steady state blood concentrations.

Everolimus was determined in whole blood by highperformance liquid chromatography with tandem mass spectrometry (HPLC-MS/MS) after protein precipitation with acetonitrile using the deuterated stable isotope everolimus- $\mathrm{d}_{4}$ as internal standard. Capecitabine and the metabolites 5'-deoxy-5- fluorocytidine (5'-dFCR), 5'-deoxy-5- fluorouridine (5'-dFUR), 5-fluorouracil (5-FU) and 5-fluorodihydrouracil $\left(\mathrm{FUH}_{2}\right)$ were determined in plasma by a validated HPLC-MS/MS method as described previously [33]. The pharmacokinetic parameters were calculated using PK Solutions 2.0 (Summit Research Services, Montrose, CO 81401; www.summitpk.com) and included the area under the concentration-time curve (AUC), maximum concentration $\left(\mathrm{C}_{\max }\right)$, time to $\mathrm{C}_{\max }\left(\mathrm{t}_{\max }\right)$, and in addition for everolimus trough concentrations at steady state $\left(\mathrm{C}_{0}^{\mathrm{ss}}\right)$.

\section{Statistical analysis}

Descriptive statistics were used for evaluation of the safety, efficacy and pharmacokinetic parameters using SPSS statistics version 17.0.

Table 2 Treatment administration of the combination of everolimus and capecitabine by dose level

\begin{tabular}{|c|c|c|c|c|c|}
\hline & Dose level 1 & Dose level 2 & Dose level 3 & Dose level 4 & All \\
\hline Daily dose of everolimus & $10 \mathrm{mg}$ & $10 \mathrm{mg}$ & $10 \mathrm{mg}$ & $10 \mathrm{mg}$ & $10 \mathrm{mg}$ \\
\hline Dose of capecitabine & $500 \mathrm{mg} / \mathrm{m}^{2} \mathrm{bid}$ & $650 \mathrm{mg} / \mathrm{m}^{2}$ bid & $800 \mathrm{mg} / \mathrm{m}^{2}$ bid & $1,000 \mathrm{mg} / \mathrm{m}^{2}$ bid & $500-1,000 \mathrm{mg} / \mathrm{m}^{2}$ bid \\
\hline Evaluable patients $(N)$ & 4 & 5 & 3 & 6 & 18 \\
\hline \multicolumn{6}{|l|}{ No. of treatment cycles, } \\
\hline Median & 2.5 & 9 & 2 & 3 & 3 \\
\hline Range & $1-15$ & $1-15$ & $2-3$ & $3-19$ & $1-19$ \\
\hline \multicolumn{6}{|c|}{ No. of treatment days with everolimus, } \\
\hline Mean \pm SD & $108 \pm 126$ & $192 \pm 141$ & $50 \pm 20$ & $168 \pm 153$ & $141 \pm 131$ \\
\hline Median & 61 & 202 & 50 & 78 & 70 \\
\hline Range & $21-290$ & $29-329$ & $30-70$ & $65-414$ & $21-414$ \\
\hline DLT & None & None & None & 1 patient & 1 patient \\
\hline
\end{tabular}

bid twice daily; $D L T$ dose-limiting toxicity; $S D$ standard deviation 


\section{Results}

In total, 18 patients with advanced solid tumors were enrolled between February 2008 and June 2010. Patient characteristics are listed in Table 1 . All patients received at least one course of treatment and were evaluable for toxicity assessments (Table 2). Overall, a total of 114 treatment cycles were given, with a median (range) of 3 (1-19) cycles per patient. Median (range) treatment duration with everolimus was 70 (21-414) days (Table 2). Four patients temporarily interrupted treatment with everolimus: in three cases due to adverse events and in one due to fever. Following treatment interruption, two patients received a $50 \%$ dose reduction of everolimus and the others continued treatment at full dose everolimus. Dose reductions for capecitabine were applied in nine patients, mostly due to adverse events.

\section{MTD and DLT}

No DLT was observed up to $800 \mathrm{mg} / \mathrm{m}^{2}$ of capecitabine bid, and none of the first three patients treated at the $1,000 \mathrm{mg} /$ $\mathrm{m}^{2}$ level developed DLT. Since capecitabine $1,000 \mathrm{mg} / \mathrm{m}^{2}$ bid was the highest predefined dose level and no DLT had occurred thus far, it was decided to include an additional three patients to ensure the tolerability of this level. In one of these additional patients, a man with advanced hepatocellular carcinoma, severe angioneurotic edema occurred

Table 3 Possibly, probably or definitively treatment related grade 1-2 and grade 3-4 adverse events reported in $2^{\mathrm{a}}$ or more patients

\begin{tabular}{|c|c|c|c|c|c|c|c|c|c|c|}
\hline \multirow{3}{*}{$\begin{array}{l}\text { Dose level } \\
\text { No. of patients } \\
\text { CTC grade }\end{array}$} & \multirow{2}{*}{\multicolumn{2}{|c|}{$\begin{array}{l}\text { Dose level } 1 \\
N=4\end{array}$}} & \multirow{2}{*}{\multicolumn{2}{|c|}{$\begin{array}{l}\text { Dose level } 2 \\
N=5\end{array}$}} & \multirow{2}{*}{\multicolumn{2}{|c|}{$\begin{array}{l}\text { Dose level } 3 \\
N=3\end{array}$}} & \multirow{2}{*}{\multicolumn{2}{|c|}{$\begin{array}{l}\text { Dose level } 4 \\
N=6\end{array}$}} & \multirow{2}{*}{\multicolumn{2}{|c|}{$\begin{array}{l}\text { Total, n (\%) } \\
N=18(100)\end{array}$}} \\
\hline & & & & & & & & & & \\
\hline & Grade $1-2$ & Grade 3-4 & Grade $1-2$ & Grade $3-4$ & Grade $1-2$ & Grade $3-4$ & Grade $1-2$ & Grade 3-4 & Grade $1-2$ & Grade $3-4$ \\
\hline \multicolumn{11}{|l|}{ Non-hematological } \\
\hline Fatigue & 1 & 2 & 1 & & 1 & 1 & 4 & & 7 (39) & $3(17)$ \\
\hline Stomatitis & 1 & & 2 & & 1 & & 5 & & $9(50)$ & \\
\hline Hand-foot syndrome & & & 3 & & & & 1 & 2 & $4(22)$ & $2(11)$ \\
\hline Nausea & & & & & 2 & 1 & 1 & & $3(17)$ & $1(6)$ \\
\hline Diarrhea & 1 & & & & 1 & & 1 & & $3(17)$ & \\
\hline Mucositis & & & 1 & & 1 & & & 1 & $2(11)$ & $1(6)$ \\
\hline Anorexia & & & 1 & & 1 & & & & $2(11)$ & \\
\hline Taste loss & & & & & & & 2 & & $2(11)$ & \\
\hline Neuropathy & & & & & & & 2 & & $2(11)$ & \\
\hline Constipation & & & & & & & 2 & & $2(11)$ & \\
\hline Skin rash & & & 1 & & & & 1 & & $2(11)$ & \\
\hline \multicolumn{11}{|l|}{ Hematology } \\
\hline Hemoglobin & 3 & & 5 & & 3 & & 4 & & $15(83)$ & \\
\hline Platelets & 2 & 1 & 2 & & 2 & & 3 & & $9(50)$ & $1(6)$ \\
\hline Leukocytes & 1 & & 2 & & 2 & & 2 & & 7 (39) & \\
\hline \multicolumn{11}{|l|}{ Clinical chemistry } \\
\hline GGT & 1 & 2 & 4 & & 1 & & 2 & 1 & $8(44)$ & $3(17)$ \\
\hline ASAT & 2 & & 3 & & 2 & & 3 & & $10(56)$ & \\
\hline ALAT & 2 & & 4 & & & & 1 & 1 & $7(39)$ & $1(6)$ \\
\hline Hypertriglyceridemia & 1 & & 3 & 1 & 1 & & 2 & 1 & 7 (39) & $2(11)$ \\
\hline AP & & 2 & 1 & & 1 & & 3 & & $5(28)$ & $2(11)$ \\
\hline Hypokalemia & 2 & & & & 2 & & 1 & & $5(28)$ & \\
\hline Hyponatremia & 2 & & 1 & & 1 & & 1 & & $5(28)$ & \\
\hline Hypercholesteremia & 1 & & 2 & & & & 1 & & $4(22)$ & \\
\hline Hyperkalemia & 2 & & & & & & 1 & & $3(17)$ & \\
\hline Bilirubin & 1 & 2 & & & & & & & $1(6)$ & $2(11)$ \\
\hline Hypercalcemia $^{a}$ & & & & & & & & 1 & & $1(6)$ \\
\hline
\end{tabular}

Numbers represent number of patients

${ }^{\text {a }}$ Grade 4 hypercalcemia occurred in one patient and was therefore included in the table 
10 days after start of treatment with everolimus (i.e. 3 days after start of capecitabine), which could however be excluded as being drug-related. Nonetheless, treatment with both capecitabine and everolimus was discontinued. Edema quickly resolved, and after 5 days of treatment interruption, treatment was resumed and the first cycle completed with a $50 \%$ and $33 \%$ reduced dose of everolimus and capecitabine, respectively. Subsequently, the patient developed mucositis grade 3 and thrombocytopenia grade 2 for which start of the second cycle with capecitabine had to be delayed by more than 4 weeks. This toxicity was considered intolerable and dose-limiting. Since none of the other five patients treated at the $1,000 \mathrm{mg} / \mathrm{m}^{2}$ level developed DLT, everolimus $5 \mathrm{mg}$ bid continuously combined with capecitabine $1,000 \mathrm{mg} / \mathrm{m}^{2}$ bid for 14 days every 3 weeks was declared the MTD.

\section{Safety}

Table 3 lists the treatment-related CTC grade 1-2 and grade 3-4 adverse events per dose level. The most frequently reported clinical toxicities of any grade included fatigue $(56 \%)$, stomatitis $(50 \%)$, hand-foot syndrome $(33 \%)$ and nausea $(22 \%)$. Other clinical toxicities included diarrhea and mucositis (both 17\%), and anorexia, taste loss, constipation, skin rash and neuropathy (all 11\%). Clinical toxicities were never severe ( $\leq$ grade 2 ), with the exception of fatigue in three patients, hand-foot syndrome in two, and nausea in one. The six patients that developed hand-foot syndrome were on average treated with $12.2 \pm 5.6$ cycles, while the average onset of hand-foot syndrome was after $4.6 \pm 2.3$ cycles of treatment. With $20-25 \%$ dose reductions of capecitabine, five patients were able to continue treatment safely, and one patient went off study due to disease progression.

Decreased hemoglobin was the most frequently reported drug-related hematological adverse event $(83 \%)$, followed by a decrease in platelets (56\%) and leukocytes (39\%). Except for one patient in dose level 1 with grade 3 thrombocytopenia, hematological toxicity remained always sgrade 2. Elevation of gamma-glutamyltransferase (GGT) of any grade was the most frequently reported biochemical toxicity $(61 \%)$, but appeared almost never clinically relevant (grade $\leq 2)$. Only two patients presented with GGT grade 3, and one patient with GGT grade 4, though her GGT-level was already grade 3 at baseline. Elevated levels of ASAT (56\%), ALAT (44\%) and alkaline phosphatase $(39 \%)$ were mostly of grade $\leq 2$, except for one patient in whom ALAT grade 3 occurred, and in two patients alkaline phosphatase grade 3. Hypertriglyceridemia and hypercholesteremia occurred in $50 \%$ and $22 \%$ of the patients, respectively. Hypercalcemia was the second grade 4 toxicity that occurred in this study, which developed after the $3^{\text {rd }}$ cycle of treatment in a patient treated in dose level 4. Due to clinical progression, the patient went off study and was given pamidronate, however a possible relationship with study medication could not be excluded.

\section{Pharmacokinetics of everolimus and capecitabine}

Blood samples for pharmacokinetic analyses of everolimus and capecitabine plus metabolites were obtained from 17 to 14 patients, respectively. Pharmacokinetic parameters are provided in Table 4. Everolimus showed a rapid absorption with a median (range) time to reach maximum blood concentrations of $1(0.5-4)$ hour. Steady state for ever-

Table 4 Pharmacokinetic parameters of everolimus, capecitabine and capecitabine metabolites

\begin{tabular}{llccc}
\hline Drug interaction & Patients with values $(N)$ & $\mathrm{T}_{\max }(\mathrm{hr})$ & $\mathrm{C}_{\max }(\mathrm{ng} / \mathrm{mL})$ & $\mathrm{AUC}(\mathrm{hr} * \mathrm{ng} / \mathrm{mL})$ \\
\hline Everolimus without capecitabine & 15 & $1.0(0.5-4.0)$ & $50 \pm 23$ & $302 \pm 97$ \\
Everolimus with capecitabine & 17 & $1.0(0.5-4.0)$ & $52 \pm 21$ & $290 \pm 114$ \\
Capecitabine without everolimus & 12 & $0.5(0.5-2.0)$ & $5627 \pm 5815$ & $5104 \pm 3479$ \\
Capecitabine with everolimus & 11 & $1.0(0.5-2.0)$ & $3864 \pm 3247$ & $4575 \pm 2285$ \\
5'-dFCR without everolimus & 14 & $1.0(0.5-2.0)$ & $6972 \pm 3069$ & $11994 \pm 5150$ \\
5'-dFCR with everolimus & 13 & $1.5(0.5-4.0)$ & $6019 \pm 2343$ & $11513 \pm 3458$ \\
5'-dFUR without everolimus & 14 & $1.0(0.5-2.0)$ & $6739 \pm 3438$ & $9773 \pm 3113$ \\
5'-dFUR with everolimus & 13 & $1.5(0.5-4.0)$ & $5357 \pm 3048$ & $209 \pm 3070$ \\
5-FU without everolimus & 7 & $0.5(0.5-4.0)$ & $203 \pm 230$ & $268 \pm 219$ \\
5-FU with everolimus & 6 & $1.0(0.5-4.0)$ & $157 \pm 120$ & $264 \pm 170$ \\
FUH ${ }_{2}$ without everolimus & 11 & $2.0(1.0-4.0)$ & $817 \pm 301$ & $2275 \pm 730$ \\
FUH 2 with everolimus & 10 & $2.0(1.0-4.0)$ & $782 \pm 482$ & $2805 \pm 1976$
\end{tabular}

tmax values are median (range), the other parameters are mean \pm standard deviations

Cmax maximum concentration; Tmax time to Cmax; AUC Area under the concentration-time curve; $h r$ hour; $n g / m L$ nanogram per millilitre; $5^{\prime}$ $d F C R$ 5'-deoxy-5-fluorocytidine; 5'-dFUR 5'-deoxy-5-fluorouridine; 5-FU 5-fluorouracil; FUH2 5-fluorodihydrouracil 
olimus was achieved by day 4 of treatment (Fig. 1a). Steady state was stable and remained steady at least up to day 29 (the last analyzed trough sample in this study) with an average $( \pm \mathrm{SD})$ concentration of $\mathrm{C}_{0}{ }^{\mathrm{ss}}=18( \pm 8.5) \mathrm{ng} / \mathrm{mL}$. This demonstrates that no induction or inhibition of
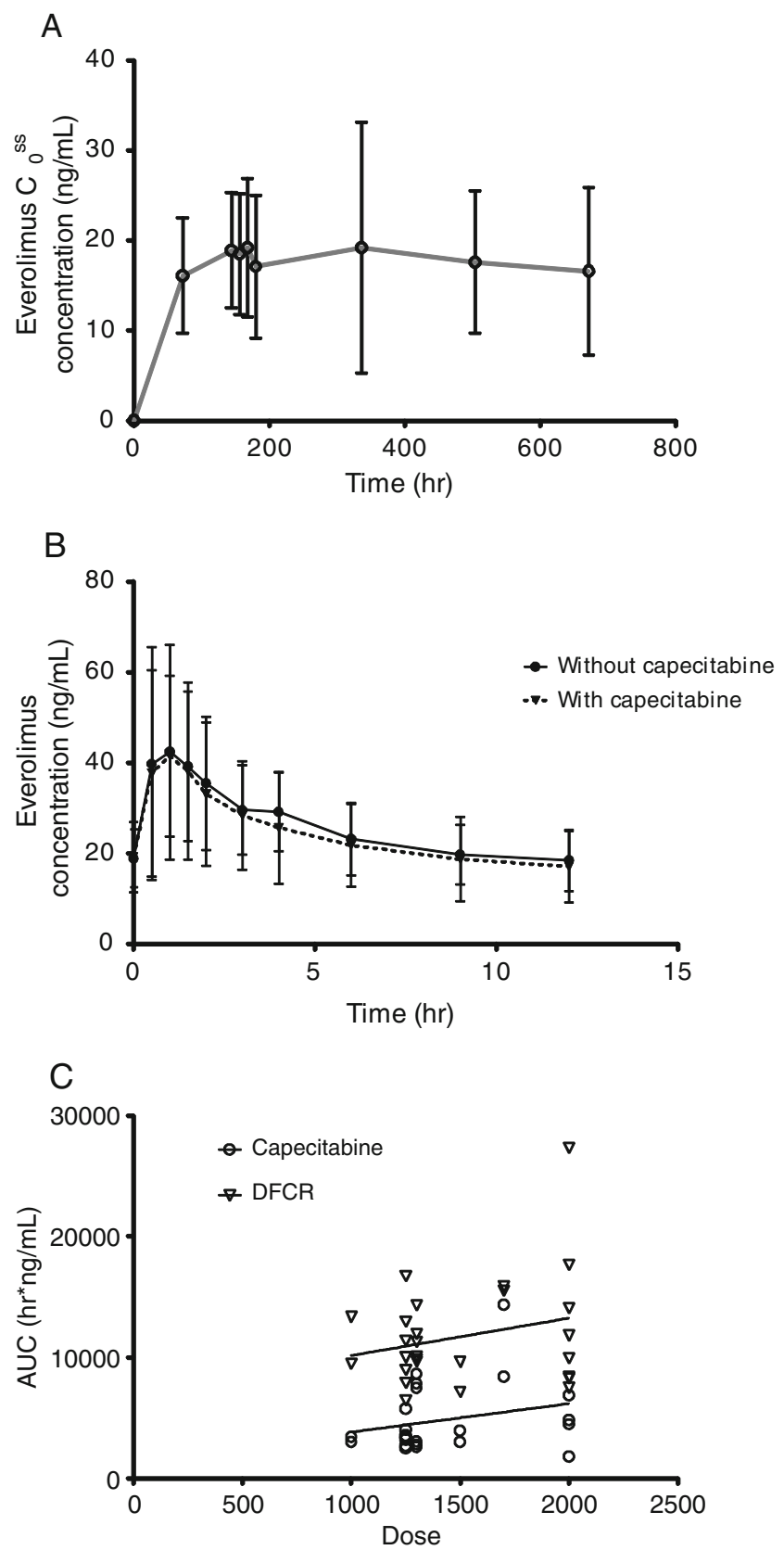

Fig. 1 a Mean (standard deviation) $\mathrm{C}_{\text {trough }}\left(\mathrm{C}_{0}{ }^{\mathrm{ss}}\right)$ concentrations of everolimus in whole blood assessed at days 1, 4, 7, 8, 15, 22 and 29 from start of treatment at a dose $5 \mathrm{mg}$ twice daily, b mean (standard deviation) concentrations of everolimus in whole blood during a $12 \mathrm{~h}$ interval at a dose of $5 \mathrm{mg}$ bid at steady state alone (circles, solid line) and with (triangles, dotted line) capecitabine, and $\mathbf{c}$ scatter plot of the administered dose of capecitabine versus the observed area under the plasma-concentration time curve (AUC) of capecitabine and dFCR. (Not shown for other capecitabine metabolites for the sake of clarity) metabolism of everolimus occurred. The mean half-life for everolimus was $t_{1 / 2}=15( \pm 8.2)$ hours. Furthermore, there was a linear relationship between the AUC of everolimus within a $12 \mathrm{~h}$ dosing interval $\left(\mathrm{AUC}_{0-12}\right)$ and the $\mathrm{C}_{0}{ }^{\mathrm{ss}}$ concentration $\left(r^{2}=0.67\right)$. No effect was observed of capecitabine on the pharmacokinetics of everolimus (Figs. $1 \mathrm{~b}$ and 2a). The $\mathrm{AUC}_{0-12}$ of everolimus at steady state alone and with capecitabine was $302 \pm 97 \mathrm{~h} * \mathrm{ng} / \mathrm{mL}$ and $290 \pm 114 \mathrm{~h} * \mathrm{ng} / \mathrm{mL}$, respectively. The inter-patient variability of the exposure to everolimus expressed as the coefficient of variation $(\% \mathrm{CV})$ was $36 \%$.

Capecitabine was rapidly absorbed and the median time to reach $C_{\max }$ was $1(0.5-2)$ hour. Plasma concentrations for capecitabine metabolites peaked within 1-2 $\mathrm{h}$ after absorption. Since the dose of capecitabine very poorly correlated with the AUCs of capecitabine and its main metabolites 5'dFCR, 5'-dFUR, 5-FU and $\mathrm{FUH}_{2}\left(\mathrm{r}^{2}=0.064,0.063,0.063\right.$, 0.13 and 0.14 , respectively), the pharmacokinetic parameters were not dose-corrected (Fig. 1c). Everolimus did not interact with the pharmacokinetics of capecitabine. The AUC of capecitabine alone and with everolimus was $5.1 \pm$ $3.5 \mathrm{~h}^{*} \mathrm{mg} / \mathrm{L}$ and $4.6 \pm 2.3 \mathrm{~h} * \mathrm{mg} / \mathrm{L}$, respectively. Furthermore, $\mathrm{C}_{\max }$ and $\mathrm{t}_{\max }$ of capecitabine did not differ between capecitabine alone or with everolimus. Likewise, no differences in the AUC, $C_{\max }$ and $t_{\max }$ for capecitabine metabolites were observed with concomitantly everolimus (Table 4 and Fig. 2b-f). The inter-patient variabilities in the AUC for capecitabine, 5'-dFCR, 5'-dFUR, 5-FU and $\mathrm{FUH}_{2}$ were $\% \mathrm{CV}=60 \%, 37 \%, 32 \%, 71 \%$ and $57 \%$, respectively.

\section{Efficacy}

Overall, 14 patients were evaluable for response by RECIST 1.0: three patients had a confirmed partial response, four had stable disease and seven had progression of disease. Four patients could not be evaluated for response, but had clinical progression of disease, and therefore withdrew early.

\section{Discussion}

This study explored the safety, pharmacokinetics and preliminary efficacy of the combination of capecitabine with the oral mTOR inhibitor everolimus in patients with advanced solid malignancies. Treatment with everolimus combined with capecitabine was generally well tolerated and showed an acceptable toxicity profile. In total, one DLT (mucositis grade 3) was observed, which occurred in one out of six patients treated at the highest dose level. In this study, we did not reach the maximum of two or more DLTs out of six treated patients in any dose level. The study protocol was not amended though with an additional higher 
Fig. 2 Individual patient area under the concentration-time curve (AUC) of a everolimus in whole blood without and with capecitabine, $b$ capecitabine in plasma without and with everolimus, c dFCR in plasma without and with everolimus, $\mathrm{d}$ dFUR in plasma without and with everolimus, e 5-FU in plasma without and with everolimus and $\mathrm{fFUH} 2$ in plasma without and with everolimus
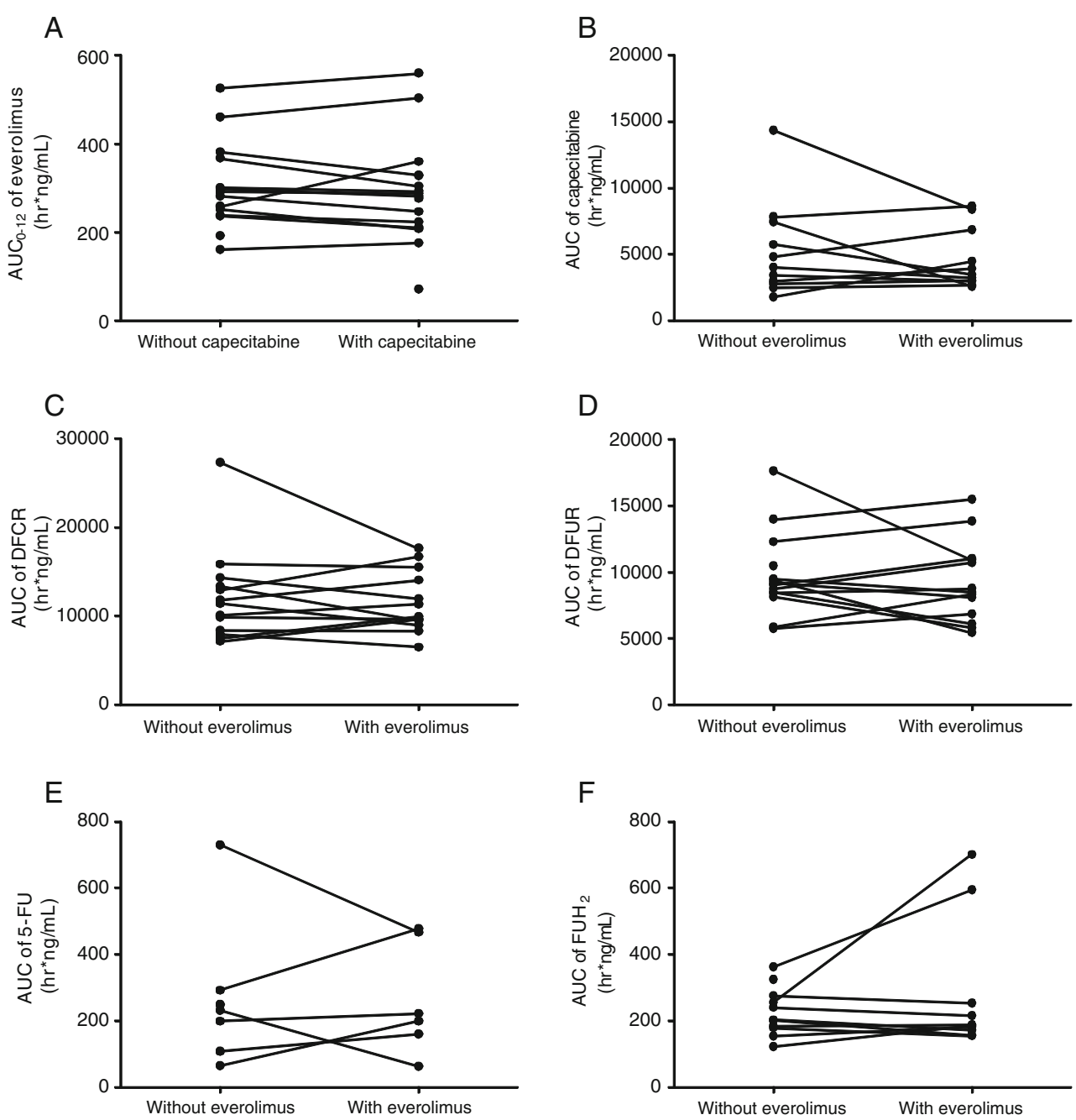

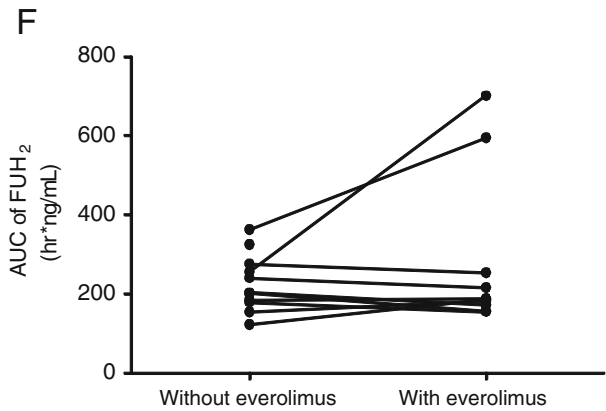

dose level, given the fact that dose reductions of capecitabine were indicated in $50 \%$ of all patients during treatment. This was mostly due to hand-foot syndrome, for which the dose of capecitabine was reduced by $25 \%$ after on average 6 cycles of treatment. Therefore, our recommendation for further phase II trials with this combination is everolimus $10 \mathrm{mg}$ daily continuously combined with $1,000 \mathrm{mg} / \mathrm{m}^{2}$ capecitabine twice daily for 14 days in 3-weekly cycles.

The most commonly reported treatment-related clinical side effects were fatigue, stomatitis and hand-foot syndrome. Hand-foot syndrome can be attributed to capecitabine, since this has not been observed before in single agent everolimus trials. This well-known side effect of capecitabine resulted in only modest dose reductions of capecitabine in our patients. Although stomatitis is a common adverse event of both capecitabine and everolimus as single agent as well, this overlapping toxicity always remained mild to moderate in severity in this study and was not dose-limiting. Moreover, the frequency of stomatitis in this study was similar compared to studies with single agent everolimus, which suggests that there is no, or only a marginal additive toxic effect of capecitabine.

The frequency of fatigue was similar to that of single agent studies with everolimus as well [21-24]. Other adverse events included, diarrhea, anorexia, taste loss, neuropathy and skin rash, but remained non-severe. While in this study the oral treatment regimen of everolimus combined with capecitabine appeared safe and feasible, it is of note that a previous phase I study in which the intravenous mTOR inhibitor temsirolimus was combined with infusional 5-FU and leucovorin, stomatitis/mucositis occurred at all dose-levels and was dose-limiting. Moreover, this combination also resulted in treatment-related fatal bowel perforation in two patients [34]. Similarly, another phase I study reported that everolimus $20 \mathrm{mg}$ per week combined with the antimetabolite gemcitabine $600 \mathrm{mg} / \mathrm{m}^{2}$ on days 1,8 and 15 in 4-weekly cycles was not tolerated due to severe myelosuppression [27]. However, no such unexplained severe toxicities were observed in our study, which has important implications for further studies. 
Similarly to what we report in this trial, both previous studies did not show a pharmacokinetic interaction between the mTOR inhibitor and the antimetabolite. This suggests that drug interactions at a pharmacodynamic level, or schedule differences might explain the observed variations in severity of overlapping toxicities when different mTOR inhibitors and cytotoxic antimetabolites are combined.

Lim et al. recently published their trial of everolimus combined with capecitabine in Korean patients with advanced gastric cancer [31]. In contrast to their findings of a rather low maximum-tolerated dose (capecitabine $650 \mathrm{mg} / \mathrm{m}^{2}$ ), our study is the first to demonstrate the feasibility of this combination at doses with proven single agent efficacy in a number of tumors. This surprisingly large difference $\left(650 \mathrm{mg} / \mathrm{m}^{2}\right.$ versus $1,000 \mathrm{mg} / \mathrm{m}^{2}$ capecitabine bid $)$ between the studies might possibly be caused by the gastrectomy in more than half of the patients in the Korean trial already had undergone. It is known that gastrectomy results in a higher systemic exposure and higher $\mathrm{C}_{\max }$ to capecitabine, possibly affecting tolerability [35].

The pharmacokinetic profile of everolimus assessed in this study showed a comparable absorption, systemic exposure, and trough concentration as in other white and Japanese patient cohorts treated with $10 \mathrm{mg}$ everolimus per day $[22,23,25]$. The absorption was relatively fast with a median time to $\mathrm{C}_{\max }$ of $1 \mathrm{~h}$, and steady state was reached within 4 days of treatment. Likewise, capecitabine was rapidly absorbed, and the AUC, $\mathrm{C}_{\max }$ and time to $\mathrm{C}_{\max }$ were in line with previously reported data [36].

Since this was a phase I study, efficacy was not a primary endpoint; nonetheless, 14 patients were evaluable for response. In seven patients a clinical response, including prolonged disease stabilization was achieved. The three patients with a partial response (two patients with pancreatic cancer) and half of patients with stable disease had not received any prior chemotherapy at study entry. But because of the minimal survival advantage of gemcitabine in pancreatic cancer, first line treatment with experimental anticancer therapy is considered a reasonable alternative in this group of patients. Obviously, the relative contribution of everolimus to this clinical benefit in these patients is difficult to determine. However, previous studies with single agent everolimus rarely showed better responses than prolonged disease stabilization.

In conclusion, we showed that everolimus twice daily in a total dose of $10 \mathrm{mg}$ /day (5 mg bid) continuously combined with capecitabine $1,000 \mathrm{mg} / \mathrm{m}^{2}$ for 14 days every 3 weeks is a safe and tolerable oral treatment regimen, and achieved prolonged clinical benefit in a significant number of patients. Toxicities were generally mild to moderate severe and were well manageable. No unexplained severe toxicities were reported, and no pharmacokinetic interaction between everolimus and capecitabine was observed. There- fore, the results obtained in this study provided for us a solid basis for our ongoing phase II trial of everolimus and capecitabine in pancreatic cancer patients (Trial identifier NTC01079702. Moreover, the interesting balance between efficacy and burden on the patient of this treatment combination is attractive to investigate in other tumor types as well.

Conflict of interest The authors declare that they have no conflicts of interest.

Funding This work was supported by the Academic Medical Center Amsterdam and the Netherlands Cancer Institute. Everolimus was provided by Novartis.

Open Access This article is distributed under the terms of the Creative Commons Attribution Noncommercial License which permits any noncommercial use, distribution, and reproduction in any medium, provided the original author(s) and source are credited.

\section{References}

1. LoPiccolo J, Blumenthal GM, Bernstein WB, Dennis PA (2008) Targeting the PI3K/Akt/mTOR pathway: effective combinations and clinical considerations. Drug Resist Updat 11:32-50

2. Aoki M, Blazek E, Vogt PK (2001) A role of the kinase mTOR in cellular transformation induced by the oncoproteins P3k and Akt. Proc Natl Acad Sci USA 98:136-141

3. Beuvink I, Boulay A, Fumagalli S, Zilbermann F, Ruetz S, O'Reilly T, Natt F, Hall J, Lane HA, Thomas G (2005) The mTOR inhibitor RAD001 sensitizes tumor cells to DNA-damaged induced apoptosis through inhibition of $\mathrm{p} 21$ translation. Cell 120:747-759

4. Boulay A, Zumstein-Mecker S, Stephan C, Beuvink I, Zilbermann F, Haller R, Tobler S, Heusser C, O'Reilly T, Stolz B, Marti A, Thomas G, Lane HA (2004) Antitumor efficacy of intermittent treatment schedules with the rapamycin derivative RAD001 correlates with prolonged inactivation of ribosomal protein S6 kinase 1 in peripheral blood mononuclear cells. Cancer Res 64:252-261

5. Boulay A, Rudloff J, Ye J, Zumstein-Mecker S, O’Reilly T, Evans DB, Chen S, Lane HA (2005) Dual inhibition of mTOR and estrogen receptor signaling in vitro induces cell death in models of breast cancer. Clin Cancer Res 11:5319-5328

6. Seeliger H, Guba M, Kleespies A, Jauch KW, Bruns CJ (2007) Role of mTOR in solid tumor systems: a therapeutical target against primary tumor growth, metastases, and angiogenesis. Cancer Metastasis Rev 26:611-621

7. Majumder PK, Febbo PG, Bikoff R, Berger R, Xue Q, McMahon LM, Manola J, Brugarolas J, McDonnell TJ, Golub TR, Loda M, Lane HA, Sellers WR (2004) mTOR inhibition reverses Aktdependent prostate intraepithelial neoplasia through regulation of apoptotic and HIF-1-dependent pathways. Nat Med 10:594-601

8. Goudar RK, Shi Q, Hjelmeland MD, Keir ST, McLendon RE, Wikstrand CJ, Reese ED, Conrad CA, Traxler P, Lane HA, Reardon DA, Cavenee WK, Wang XF, Bigner DD, Friedman HS, Rich JN (2005) Combination therapy of inhibitors of epidermal growth factor receptor/vascular endothelial growth factor receptor 2 (AEE788) and the mammalian target of rapamycin (RAD001) offers improved glioblastoma tumor growth inhibition. Mol Cancer Ther 4:101-112

9. Mabuchi S, Altomare DA, Cheung M, Zhang L, Poulikakos PI, Hensley HH, Schilder RJ, Ozols RF, Testa JR (2007) RAD001 
inhibits human ovarian cancer cell proliferation, enhances cisplatin-induced apoptosis, and prolongs survival in an ovarian cancer model. Clin Cancer Res 13:4261-4270

10. Khariwala SS, Kjaergaard J, Lorenz R, Van Lente F, Shu S, Strome M (2006) Everolimus (RAD) inhibits in vivo growth of murine squamous cell carcinoma (SCC VII). Laryngoscope 116:814-820

11. Zitzmann K, De Toni EN, Brand S, Goke B, Meinecke J, Spottl G, Meyer HH, Auernhammer CJ (2007) The novel mTOR inhibitor RAD001 (everolimus) induces antiproliferative effects in human pancreatic neuroendocrine tumor cells. Neuroendocrinology 85:54-60

12. Matsuzaki T, Yashiro M, Kaizaki R, Yasuda K, Doi Y, Sawada T, Ohira M, Hirakawa K (2009) Synergistic antiproliferative effect of mTOR inhibitors in combination with 5-fluorouracil in scirrhous gastric cancer. Cancer Sci

13. Bu X, Le C, Jia F, Guo X, Zhang L, Zhang B, Wu M, Wei L (2008) Synergistic effect of mTOR inhibitor rapamycin and fluorouracil in inducing apoptosis and cell senescence in hepatocarcinoma cells. Cancer Biol Ther 7:392-396

14. Seeliger H, Guba M, Koehl GE, Doenecke A, Steinbauer M, Bruns CJ, Wagner C, Frank E, Jauch KW, Geissler EK (2004) Blockage of 2-deoxy-D-ribose-induced angiogenesis with rapamycin counteracts a thymidine phosphorylase-based escape mechanism available for colon cancer under 5-fluorouracil therapy. Clin Cancer Res 10:1843-1852

15. Lee KH, Hur HS, Im SA, Lee J, Kim HP, Yoon YK, Han SW, Song SH, Oh DY, Kim TY, Bang YJ (2010) RAD001 shows activity against gastric cancer cells and overcomes 5-FU resistance by downregulating thymidylate synthase. Cancer Lett 299:22-28

16. Motzer RJ, Escudier B, Oudard S, Hutson TE, Porta C, Bracarda S, Grunwald V, Thompson JA, Figlin RA, Hollaender N, Urbanowitz G, Berg WJ, Kay A, Lebwohl D, Ravaud A (2008) Efficacy of everolimus in advanced renal cell carcinoma: a double-blind, randomised, placebo-controlled phase III trial. Lancet 372:449-456

17. Amato RJ, Jac J, Giessinger S, Saxena S, Willis JP (2009) A phase 2 study with a daily regimen of the oral mTOR inhibitor RAD001 (everolimus) in patients with metastatic clear cell renal cell cancer. Cancer 115:2438-2446

18. Wolpin BM, Hezel AF, Abrams T, Blaszkowsky LS, Meyerhardt JA, Chan JA, Enzinger PC, Allen B, Clark JW, Ryan DP, Fuchs CS (2009) Oral mTOR inhibitor everolimus in patients with gemcitabinerefractory metastatic pancreatic cancer. J Clin Oncol 27:193-198

19. Yao JC, Shah MH, Ito T, Bohas CL, Wolin EM, Van CE, Hobday TJ, Okusaka T, Capdevila J, de Vries EG, Tomassetti P, Pavel ME, Hoosen S, Haas T, Lincy J, Lebwohl D, Oberg K (2011) Everolimus for advanced pancreatic neuroendocrine tumors. $\mathrm{N}$ Engl J Med 364:514-523

20. Ellard SL, Clemons M, Gelmon KA, Norris B, Kennecke H, Chia S, Pritchard K, Eisen A, Vandenberg T, Taylor M, Sauerbrei E, Mishaeli M, Huntsman D, Walsh W, Olivo M, McIntosh L, Seymour L (2009) Randomized phase II study comparing two schedules of everolimus in patients with recurrent/metastatic breast cancer: NCIC Clinical Trials Group IND.163. J Clin Oncol 27:4536-4541

21. Soria JC, Shepherd FA, Douillard JY, Wolf J, Giaccone G, Crino L, Cappuzzo F, Sharma S, Gross SH, Dimitrijevic S, Di Scala L, Gardner H, Nogova L, Papadimitrakopoulou V (2009) Efficacy of everolimus (RAD001) in patients with advanced NSCLC previously treated with chemotherapy alone or with chemotherapy and EGFR inhibitors. Ann Oncol 20:1674-1681

22. O'Donnell A, Faivre S, Burris HA III, Rea D, Papadimitrakopoulou V, Shand N, Lane HA, Hazell K, Zoellner U, Kovarik JM, Brock C, Jones S, Raymond E, Judson I (2008) Phase I pharmacokinetic and pharmacodynamic study of the oral mammalian target of rapamycin inhibitor everolimus in patients with advanced solid tumors. J Clin Oncol 26:1588-1595

23. Okamoto I, Doi T, Ohtsu A, Miyazaki M, Tsuya A, Kurei K, Kobayashi K, Nakagawa K (2010) Phase I clinical and pharmaco- kinetic study of RAD001 (everolimus) administered daily to Japanese patients with advanced solid tumors. Jpn J Clin Oncol 40:17-23

24. Tabernero J, Rojo F, Calvo E, Burris H, Judson I, Hazell K, Martinelli E, Cajal S, Jones S, Vidal L, Shand N, Macarulla T, Ramos FJ, Dimitrijevic S, Zoellner U, Tang P, Stumm M, Lane HA, Lebwohl D, Baselga J (2008) Dose- and schedule-dependent inhibition of the mammalian target of rapamycin pathway with everolimus: a phase I tumor pharmacodynamic study in patients with advanced solid tumors. J Clin Oncol 26:1603-1610

25. Campone M, Levy V, Bourbouloux E, Berton Rigaud D, Bootle D, Dutreix C, Zoellner U, Shand N, Calvo F, Raymond E (2009) Safety and pharmacokinetics of paclitaxel and the oral mTOR inhibitor everolimus in advanced solid tumours. Br J Cancer 100:315-321

26. Andre F, Campone M, O'Regan R, Manlius C, Massacesi C, Sahmoud T, Mukhopadhyay P, Soria JC, Naughton M, Hurvitz SA (2010) Phase I study of everolimus plus weekly paclitaxel and trastuzumab in patients with metastatic breast cancer pretreated with trastuzumab. J Clin Oncol 28:5110-5115

27. Pacey S, Rea D, Steven N et al (2004) Results of a phase 1 clinical trial investigation a combination of the oral mTOR-inhibitor Everolimus (E, RAD001) and Gemcitabine (GEM) in patients (pts) with advanced cancers. J Clin Oncol 22(14Supplement):3120, Ref Type: Abstract

28. Milton DT, Riely GJ, Azzoli CG, Gomez JE, Heelan RT, Kris MG, Krug LM, Pao W, Pizzo B, Rizvi NA, Miller VA (2007) Phase 1 trial of everolimus and gefitinib in patients with advanced nonsmall-cell lung cancer. Cancer 110:599-605

29. Hainsworth JD, Infante JR, Spigel DR, Peyton JD, Thompson DS, Lane CM, Clark BL, Rubin MS, Trent DF, Burris HA III (2010) Bevacizumab and everolimus in the treatment of patients with metastatic melanoma: a phase 2 trial of the Sarah Cannon Oncology Research Consortium. Cancer 116:4122-4129

30. Baselga J, Semiglazov V, van Dam P, Manikhas A, Bellet M, Mayordomo J, Campone M, Kubista E, Greil R, Bianchi G, Steinseifer J, Molloy B, Tokaji E, Gardner H, Phillips P, Stumm M, Lane HA, Dixon JM, Jonat W, Rugo HS (2009) Phase II randomized study of neoadjuvant everolimus plus letrozole compared with placebo plus letrozole in patients with estrogen receptor-positive breast cancer. J Clin Oncol 27:2630-2637

31. Lim T, Lee J, Lee DJ, Lee HY, Han B, Baek KK, Ahn HK, Lee SJ, Park SH, Park JO, Park YS, Lim HY, Kim KM, Kang WK (2011) Phase I trial of capecitabine plus everolimus (RAD001) in patients with previously treated metastatic gastric cancer. Cancer Chemother Pharmacol

32. Therasse P, Arbuck SG, Eisenhauer EA, Wanders J, Kaplan RS, Rubinstein L, Verweij J, Van Glabbeke M, van Oosterom AT, Christian MC, Gwyther SG (2000) New guidelines to evaluate the response to treatment in solid tumors. European Organization for Research and Treatment of Cancer, National Cancer Institute of the United States, National Cancer Institute of Canada. J Natl Cancer Inst 92:205-216

33. Vainchtein LD, Rosing H, Schellens JH, Beijnen JH (2009) A new, validated HPLC-MS/MS method for the simultaneous determination of the anti-cancer agent capecitabine and its metabolites: 5'deoxy-5-fluorocytidine, 5'-deoxy-5-fluorouridine, 5-fluorouracil and 5-fluorodihydrouracil, in human plasma. Biomed Chromatogr

34. Punt CJ, Boni J, Bruntsch U, Peters M, Thielert C (2003) Phase I and pharmacokinetic study of CCI-779, a novel cytostatic cellcycle inhibitor, in combination with 5-fluorouracil and leucovorin in patients with advanced solid tumors. Ann Oncol 14:931-937

35. Deenen MJ, Boot H, Dubbelman R, Jansen EPM, Beijnen JH, Verheij M, Schellens JHM, Cats A (2011) The effect of gastric surgery and radiotherapy on the exposure to capecitabine. Br J Clin Pharmacol 70(6):918, Ref Type: Abstract

36. Reigner B, Blesch K, Weidekamm E (2001) Clinical pharmacokinetics of capecitabine. Clin Pharmacokinet 40:85-104 